\title{
Spotted bone disease
}

\author{
Riddhi Dasgupta, Nihal Thomas
}

Department of Endocrinology, Diabetes and Metabolism, Christian Medical College, Vellore, Tamil Nadu, India

\section{Correspondence to} Dr Nihal Thomas, nihal_thomas@yahoo.com

Accepted 8 April 2015

\section{Q Crosshark}

To cite: Dasgupta $\mathrm{R}$ Thomas N. BMJ Case Rep Published online: [please include Day Month Year] doi:10.1136/bcr-2014208422

\section{DESCRIPTION}

Osteopoikilosis, a benign autosomal dominant bone disorder, is an unusual condition that can often be misdiagnosed as a sinister primary bone anomaly or as metastatic bony lesions. We report a case of osteopoikilosis in a 29-year-old Indian man.

A 29-year-old unmarried man, born of nonconsanguineous parents, presented with a history of low back pain of 2 years duration, aggravated on prolonged walking, standing or strenuous exercise. There were no other associated symptoms and his family history was unremarkable. Clinical examination including examination of the musculoskeletal system was essentially normal. Biochemical investigations revealed haemoglobin of $13.6 \mathrm{gm} / \mathrm{dL}$, total leucocyte count of $7500 / \mathrm{mm}^{3}$ with a normal differential count and a normal erythrocyte sedimentation rate. The patient's had a serum creatinine level of $0.8 \mathrm{mg} / \mathrm{dL}$ (normal $0.6-1.2 \mathrm{mg} / \mathrm{dL}$ ), corrected serum calcium of $9.2 \mathrm{mg} / \mathrm{dL}$ (normal $8.3-10.4 \mathrm{mg}$ ) $\mathrm{dL}$ ), serum phosphate of $3.2 \mathrm{mg} / \mathrm{dL}$ (normal $2.6-$ $4.5 \mathrm{mg} / \mathrm{dL}$ ), serum alkaline phosphatase of $74 \mathrm{IU} / \mathrm{dL}$ (normal 40-125 IU/dL) and serum 25-hydroxyvitamin D level of $38 \mathrm{ng} / \mathrm{dL}$. X-ray of the pelvis with hip joints and bilateral lower limbs was suggestive of multiple well circumscribed, ovoid, radiodense bony lesions in the pelvis (figure 1) and proximal femur on both sides (figure 2). X-ray of the chest was normal and a bone scan did not reveal any foci of abnormal uptake in the ribs, vertebral bodies or diaphyses of the long bones, thereby ruling out metastatic bone disease. In view of the clinical and radiological presentation, a diagnosis of osteopoikilosis was established. The patient was advised physiotherapy and analgaesics for pain relief.

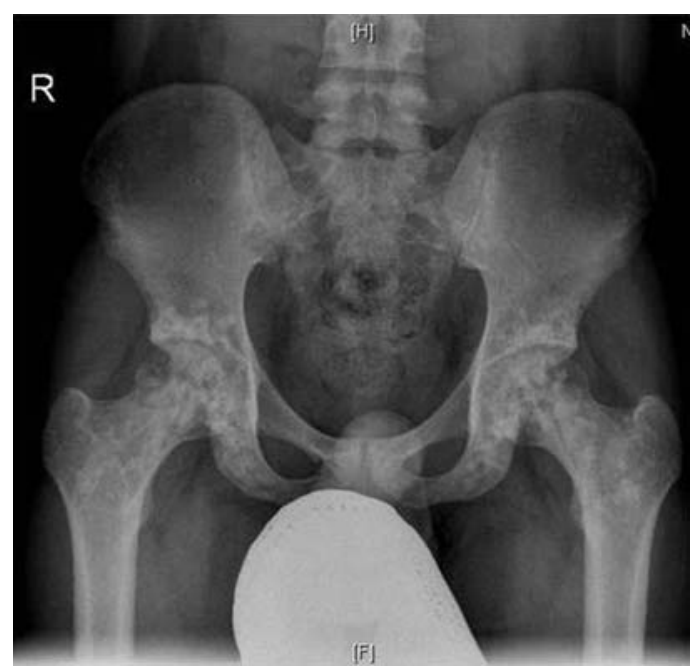

Figure 1 Anteroposterior view X-ray of the pelvis showing well-defined, small punctuate sclerotic clusters of lesions surrounding the pubic rami and hip joints bilaterally-typical of osteopoikilosis.

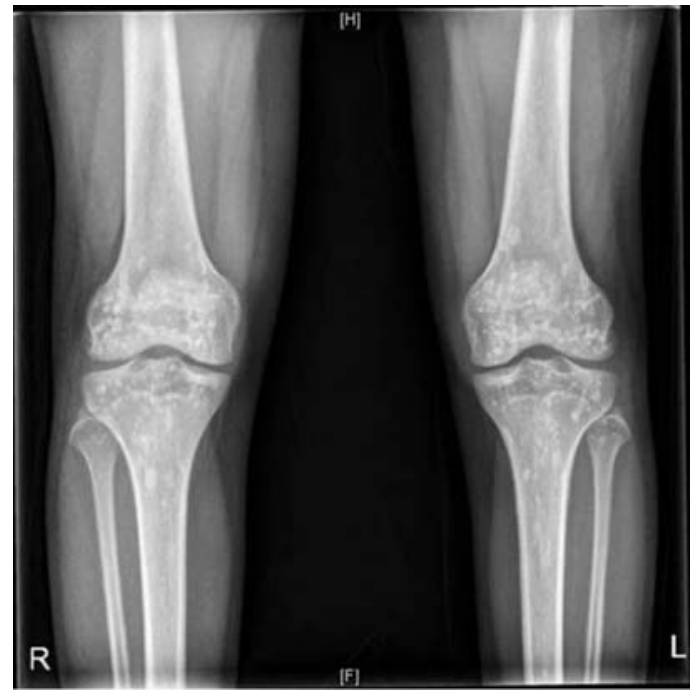

Figure 2 Anteroposterior view X-ray of the knee showing similar well-defined, small punctuate sclerotic clusters of lesion surrounding the knee joints bilaterally -typical for osteopoikilosis.

Osteopoikilosis, also known as 'spotted bone disease', is radiologically characterised by small areas of ovoid sclerotic bony lesions ${ }^{1}$ ranging in size from a few millimetres to $1 \mathrm{~cm}$, and found in close proximity with the normal cancellous zones. The disorder may appear in any age group between 15 and 60 years and the major sites of involvement include long tubular bones, carpal bones, tarsal bones, pelvis, sacrum and scapulae, while the ribs, clavicle, spine and skull are typically spared..$^{2}$ The disorder is not symptomatic, but may be incorrectly diagnosed, leading to the performance of unnecessary expensive studies for other disorders including metastatic lesions of the skeleton. ${ }^{3}$ Family members should be screened with a radiograph of the hand and knee, and, when possible, with a pelvic X-ray.

\section{Learning points}

- Osteopoikilosis is a benign autosomal dominant bone disorder that is usually asymptomatic.

- Radiological appearance of small ovoid sclerotic bony lesions involving predominantly long tubular bones and pelvis is characteristic.

- It can often be misdiagnosed as a sinister primary or metastatic bone anomaly.

- This differential should always be kept in mind to avoid unwarranted and expensive investigations. 
Contributors RD and NT contributed to the write-up, conceptualisation and final draft of this article. NT overall supervised and provided final inputs to the article write-up.

Competing interests None declared.

Patient consent Obtained.

Provenance and peer review Not commissioned; externally peer reviewed.

\section{REFERENCES}

1 Benli IT, Akalin S, Boysan E. Epidemiological, clinical and radiological aspects of osteopoikilosis. J Bone Joint Surg 1992;74:504-6.

2 Lagier R, Mbakop A, Bigler A. Osteopoikilosis: a radiological and pathological study. Skeletal Radiol 1984;11:161-8.

3 Tander B, Cengiz K, Diren B, et al. A case of osteopoikilosis mimicking metastasis on MRI study. Turk J Phy Med Rehab 2006;52:85-7.

Copyright 2015 BMJ Publishing Group. All rights reserved. For permission to reuse any of this content visit http://group.bmj.com/group/rights-licensing/permissions.

BMJ Case Report Fellows may re-use this article for personal use and teaching without any further permission.

Become a Fellow of BMJ Case Reports today and you can:

- Submit as many cases as you like

- Enjoy fast sympathetic peer review and rapid publication of accepted articles

- Access all the published articles

- Re-use any of the published material for personal use and teaching without further permission

For information on Institutional Fellowships contact consortiasales@bmjgroup.com

Visit casereports.bmj.com for more articles like this and to become a Fellow 